\title{
Music: entertainment media with millions of benefits for physical performance
}

\author{
Mochamad Ferdyan Nasrullah \\ Department of Anthropology \\ Faculty of Social and Political Sciences, Universitas Airlangga \\ Address: Jalan Dharmawangsa Dalam, Surabaya 60286 \\ E-mail: mochamadferdyan@gmail.com
}

\begin{abstract}
We cannot deny that besides having a function as an entertainment, music also has influences to its listeners. Music existence has been there and developed since thousands years ago, and in every development, Music can perform beautiful tones and meaningful messages for its listeners. Music can take the listeners to their world that will give significant influences in their lives. Music can influence the minds and brains; therefore, it can produce health by listening music. This research aims to find out the influence that we can get from listening to music, digging the information related to the benefits of music, and analyzing how music influences its listeners. The method used in this research is the quantitative approach by using the survey and questionnaire methods. The conclusion that the researcher can explain in this research is that music is not only entertainment media but music can also send the listeners' tiredness away; furthermore music brings the positive effects to its listeners. The effects that the listeners often feel are: that music can influence someone's cognitive development which covers someone's intelligence level until someone's memory and also someone's health that can reduce the blood pressure, reduce the anxiety levels, stress and depression.
\end{abstract}

Keywords : music, cognitive, health, existence

\section{Introduction}

Music has existed and developed since the ancient Greek era. Music is also considered as a culture that has its own typical characters. According to the ancient Greek myths, music was considered as the gods' or half gods' creations like Apollo, Ampion, and Orpheus and they also thought that music had a magic power that could make the human body and people's soul perfect and make the miracles in the scientific world (McNeill 2002).

We can say that music has developed fast until now. Music is considered as a need for most people in the world. Many people use music as something to accompany the daily activities. For some fans, music is not only an entertainment that can go fast from the memory, but it might become a means that gives inspiration, motivation, and dedication (Hirzi 2007). Globally, music has its own benefits for its listeners so that it can bring the positive effects towards our life continuity.

There is no doubt that music influences our life very much. The effects are clear and measurable, not only on the physical things, but also on the biological creatures especially human (Campell 2001). Human needs towards music cannot be avoided. Music comes as a need completion that always accompanies human whatever their activities every day with various reason are.

According to (Hirzi 2007), music is used as a means of connecting the minds and the heart and the heart expression means. Many individuals in the world use the music as sedative means, self entertainer, and as a means to forget the world problems for a while. Indeed, music brings the good effects for psychological matter. Therefore, with this research, the researcher will discuss the music effects towards an individual and the effects on the daily lives and its existence in the sophisticated era like today.

The purpose of this research is to know and find the information about the music existence itself and 
the influences for the listeners. Many opinions state that music is one of the culture heritages which has certain values and has meaning from the music substance itself. Therefore, this research will discuss on how the music influences the listeners and what the listeners get after they listen to the music, in what parts the music can bring the positive effects and whether the music is still needed today.

\section{Method}

The researcher used qualitative approach method with survey by using the questionnaires with random sampling character. The purpose to use questionnaires was to be able to reach the various levels especially the social media active users, starting from the teenagers until adults. The researcher considered that the social media active users used the media very rapidly. Therefore, the questionnaires were done on line and distributed through the social media and from the distributed questionnaires; the researcher could get 145 respondents. The researcher took the campus locations and also some schools in Surabaya and around. The purposes to select those locations were to get the respondents as many as possible and the respondents were from various levels so that the researcher could get the maximum and valid data.

\section{The Research Result and Discussion}

From all answers given by the respondents from the distributed questionnaires, the researcher could see the result as follows:

Table 1

The respondents who have ever listened to music

\begin{tabular}{cc}
\hline Answer Indicator & Percentage \\
\hline Yes & $100 \%$ \\
No & $0 \%$ \\
Total & $100 \%$ \\
\hline
\end{tabular}

Table 2

The kinds of music that the respondents usually listen to

\begin{tabular}{cc}
\hline Answer Indicator & Percentage \\
\hline Pop & $70,6 \%$ \\
Indie (independent music) & $8,4 \%$ \\
Rock & $4,2 \%$ \\
Jazz & $4,2 \%$ \\
Folk & $1,4 \%$ \\
EDM & $1,4 \%$ \\
Others & $9,8 \%$ \\
Total & $100 \%$ \\
\hline
\end{tabular}

For the answer of "others" the respondents mentioned some other kinds of music like murotal (religious music), metal, langgam jawa (Javanese music) acoustics, Islami (Muslim music), Mozart, dangdut (traditional music), etc.

Table 3

Respondents' reasons to listen to music

\begin{tabular}{cc}
\hline Answer Indicator & Percentage \\
\hline Reducing the boredom & $69,2 \%$ \\
Hobby & $21 \%$ \\
Killing the time & $7 \%$ \\
Others & $2,8 \%$ \\
Total & $100 \%$ \\
\hline
\end{tabular}


For the answer of "others", the respondents said that they wanted to find peace, express their feeling, cool their heart down; and if they only answered that they just wanted to listen to music, each answer indicator had the percentage $0.7 \%$ for their answer.

Table 4

The Frequencies of the Respondents to listen to music

\begin{tabular}{cc}
\hline Answer Indicator & Percentage \\
\hline $1-2$ times & $28,9 \%$ \\
$2-3$ times & $16,9 \%$ \\
$3-4$ times & $33,8 \%$ \\
Not certain & $20,4 \%$ \\
Total & $100 \%$ \\
\hline
\end{tabular}

Table 5

When the respondents usually listen to music

\begin{tabular}{cc}
\hline Answer Indicator & Percentage \\
\hline When they relax & $46,2 \%$ \\
When they sleep & $2,1 \%$ \\
When they do assignment & $25,9 \%$ \\
When they are on the way to somewhere & $4,9 \%$ \\
When they want to & $7 \%$ \\
At almost all activities & $13,9 \%$ \\
Total & $100 \%$ \\
\hline
\end{tabular}

Table 6

What the respondents feel after they listen to music

\begin{tabular}{cc}
\hline Answer Indicator & Percentage \\
\hline Happy & $8,5 \%$ \\
Entertained & $36,6 \%$ \\
Calm & $23,9 \%$ \\
Comfortable & $19,7 \%$ \\
Enjoy & $7,1 \%$ \\
So so/fine & $2,8 \%$ \\
Not feeling alone & $1,4 \%$ \\
Total & $100 \%$ \\
\hline
\end{tabular}

Table 7

Based on the respondents' experiences,

after listening to music they will have their memory on something increased or not

\begin{tabular}{cc}
\hline Answer Indicator & Percentage \\
\hline Yes & $29,4 \%$ \\
No & $12,6 \%$ \\
Probably & $31,5 \%$ \\
So so & $26,5 \%$ \\
Total & $100 \%$ \\
\hline
\end{tabular}

Table 8

Music is a must or not

\begin{tabular}{cc}
\hline Answer Indicator & Percentage \\
\hline Yes & $52,4 \%$ \\
No & $23,8 \%$ \\
Probably & $23,8 \%$ \\
Total & $100 \%$ \\
\hline
\end{tabular}


Nasrullah: Music: entertainment media with millions of benefits for physical performance

Table 9

Agree or disagree that music brings good effects on the body

\begin{tabular}{cc}
\hline Answer Indicator & Percentage \\
\hline Yes & $96,5 \%$ \\
No & $3,5 \%$ \\
Total & $100 \%$ \\
\hline
\end{tabular}

\section{Discussion}

Based on the data gotten from the questionnaire, the researcher got various data which had different percentages. The researcher could draw an outline that almost all of the respondents needed music and thought that music was a must for them. They needed music, with some reasons for example to cool the mind down, to enjoy a hobby, to accompany doing the activities, etc. It surely was in line with the opinion about the influences of the music itself.

Music really brought the good effects for the listeners. Based on Table 7, music could give influences on increasing the memory, it was proved from the existing correspondence, and they agreed and might agree towards that fact. All people could listen to music wherever and whenever they wanted without any age limitation because basically music existed for all kinds of human levels. There was no doubt that the listeners really needed music since they had already considered music as their part of their life and music would never end.

\section{Music as a Need}

Almost all human consider music as a harmony produced from melodies and influenced its listeners' mood and emotion (Halim 2002). Music is part of art that it keeps on improving and changing until now. It is unlike the listeners. According to Ellfira (2015), music is not only as an entertainment, but music also has effects on the human's life that can be connected to everything related to physics, emotion, spirituality and others. Music has its loyal listeners in which in its music itself the music brings the influences to its listeners. In the fast era like today, music itself has already become a part that cannot be possibly separated from the socials lives. It is just like what we can see in Table 3 and 4, most of the respondents really need the music to get rid of their boredom; therefore, most of them listened to music 3-4 times in a day with percentage of 38.8\%. Music itself will always exist and keeps on flowing the psychological stimulus for everyone who listens to it.

Music is well known as a strong media to stimulate body's movement to its listeners, starting from the foot tapping, head nodding, leg and hip swinging to the free dancing or more sophisticated styles (Maes et al. 2014). The melody strains can bring its listeners to their own worlds which can make the peaceful souls. We can see in the working areas, a worker always listens to music just to cool his mind down, and then someone who is jogging also uses a headset to listen to music (Santoso 2002).

\section{The Benefits of Music towards the Cognitive Development and Expression Media/Means}

In the reality, music is not only as an art and an entertainment. Music has many kinds of benefits for its listeners; one of them is the influence towards someone's ability to think and the effects towards each individual's learning achievement. According to Martopo (2008), besides being an entertainment, music is believed to have ability to reduce the stress levels, anxiety, to improve the human' intelligence, to prevent the loss of the memory, and to increase someone's motivation. Music with the low tempo for example, like Mozart, according to Kurniawan (2016) influences to slow down and balance the brain, besides that Mozart music which is soft and balance among the beat, rhythm, and the harmony can modify the brain waves therefore the music process which is heard will vibrate the nerves located in the head to trigger the emotion, and later the waves will make someone relaxed. 
Indonesian Journal of Social Sciences Volume 12 No. 01, January - June 2020, page 12-19

Beside that, music can also increase someone' memory. According to Wulandari (2009), music instrument does not influence the ability of the short term memory at all which means that music can increase the memory of the listeners. It is in line with the Table 7 above, it explained that most of the music listeners might feel their ability to memorize something becomes increased. With the improvement of someone's memory, indirectly someone will do all of the daily activities every day easily.

Music can also become a means to express or share emotion, or with other words that music is a means to express someone's emotion. Music creators from time to time have already shown their freedom to express their emotion which is related to various kinds of perception like nature, love, sadness and happiness, anger, thought, and further more they have already started to do some ways like changing the tones based on their heart condition (Martopo 2008). Then, music is released to the market share and Thousands until millions of music fans listen to the music directly which later they will also feel the emotion existed in the music. The listeners will get along with the music situation that they listen and the music can represent their feeling or their heart situation.

According to Dowling and Harwood in Juslin and Vastjall (2008) music can stimulate the strong emotional responds to people and they want to know the reason about that matter. Therefore; the music fans always want to know the meaning of the music they hear so that they can feel what the music creator want. Not only for the adults, has Music also had good effects on the children's cognitive and motorist development. Parents, who have already introduced music to their children, gradually know that the music influences the work of the brain of their children. When the children come to preschool ages, parents who usually move to accompany a song, will influence the children's passion and their interests on music. It also will make the children able to improve their expression power towards the music. It is the same as what Campbell said, according to Campbell (2001), movement that follows the music which is played will give the children better opportunities to improve the ability to measure time, the ability to coordinate, creativity and skills to solve problems.

\section{Music and Health}

Music is not only sound source that is nice listening but it also the healing source. Music as a therapy has developed supported with many researches done by the experts in the music, education and medical areas (Halim 2002). The use of music as a therapy has already become a healing alternative for a disease. Globally, the tones and melodies existed in a music will influence the brain which directly responds the nerves to send signals and it can make someone in a calm condition. Music can create the calm, comfortable, and peaceful condition for the listeners. It is suitable with what is stated in Table 9, music gives positive effects for the listeners' bodies. Therefore; if it is connected, music has a very good relation when we use it as a healing alternative in the world of health.

We can see that for today, there are many treatment therapies developed to handle anxiety or pain, one of them is music therapy that can reduce the anxiety on the patient. This music therapy is proved useful in the healing processes since it can lower the pain feeling and can make the client's feeling relaxed (Kate \& Mucci 2001 in Faradisi 2012). According to Sacks in Komariyah (2016), music directly can influence the work of our muscles. Music can influence the system in our body, including the hormones in the body. Music can influence the heart beats and the blood pressure by stimulating the adrenaline hormones. Therefore; music can reduce the anxiety levels and the stress from someone.

In a mother's pregnancy, music can also have influence to the mother and her baby. The sound that is listened, music that is played, the words that are spoken when a mother is pregnant can send the love messages and entertainment to a child before he or she is born. As we will see, music that makes someone relaxed will also make a child in the mother's womb of a pregnant mother feels comfortable and well taken care directly or physiologically since the very early period (Campbell 2001).

Music cannot only do those activities, it also plays a role in the medical world namely as a medium to heal or reduce the stress and depression levels. According to Lerik and Prawitasari (2005), depression 
is a group of clinical disorder signed with the loosing of feeling control and subjective experiences with heavy suffering, symptoms appeared like sadness, despair, eating disorder, sleeping disorder, being introvert, losing concentration, losing energy, and anxiety. The music therapy itself can be beneficial if we do it with special treatment, for examples considering some aspects like: (a) we can provide our own tape recorder and music cassettes that are needed, (b) we can listen to music any time we need it and it is cheaper from the cost side, (c) we do not get the additional pressure from the societies who consider that someone who consults to a psychologist or psychiatrist has an embarrassing mental disorder (Lerik and Prawitasari 2005).

According to Potter in Djamal, Rompas, and Bawotong (2015) music is proved that it shows effects like reducing the blood pressure, and changing the time perception. A nurse can use music creatively in the various clinical situation, patients generally prefer doing something like playing a music instrument, singing a song or listening to music. Music which is from the beginning already suitable with the individual's heart situation is considered to be the best choice.

\section{The Existence of Music Today}

Universally, human being is not only a creature with orientation on life and working. Humans also need a means to get rid of their busy thoughts just to feel the peace and entertainment which are needed by the mind and the feeling. Through music, they can get peace. They can find music everywhere and every time. One of the examples according to Aguiar (2017), is online streaming music which is still on the highest level of popularity. Music listeners can choose their favorite songs freely, starting from pop, rock, indie (independent music) music, hip hop genres until keroncong (traditional music) or music that is like in Table 2 above. All music has its own influences. There are emotion and meaning contained in music which is directed to the listeners in the world.

Frankly all music is the same just like other art creation, containing entertaining character, but not all music and art work have entertaining character. There is always more strength in the term of giving meaning in the music art work which includes the contemplation language and contemplation experience in a value system which is not entertaining at all. It is impossible for people to live in sensuality without experiencing the progression in the high and soft manner. If it happens, humans will have stagnant character and they will stop in the left behind situation in vain. Therefore, music is not only tones and beautiful rhythm which comes to our ears, but it also covers all substances which covers back ground of the history of the music itself was created (Hardjana 2004).

In the development, music will always have the changes. According to Ardivitiyanto (2015), music will keep on developing so that it will go to the sub genre simultaneously that can make music itself have more complicated typical characters. Music must stay 'exist' because its influence is needed by its listeners. Based on Kurkela (Poutiainen \& Lilja 2012), music itself can work as a mind that will do the various conscious process from mental and growth activities. As the result, music can appear where ever a young individual is able to face comfortably, for examples, their fear, raising the sexuality, confusion, being frustrated, and music that is learnt unconsciously can handle various challenging problems and emotional power.

\section{Conclusion}

All things in the world are supposed to have purposes and benefits, including music. Music is a culture inheritance which has already developed since the ancient Greek era. Until today, music development grows very fast, starting from the kinds of it, music value itself, until its fans. Music cannot be separated from some people in the world because music is considered to be the part of life that must exist. Tones, melodies, until the rhythms in music give direct influences that is captured by the brain. As a result, music will influence minds and the listeners' soul. There are many kinds of music in the world, the popular ones are pop, rock, hip hop, indie (independent music), Mozart, jazz and etc. All of that music has the different influences to its 
listeners because the biggest influences given by music are from the favorite music. Most people listen to music just to entertain themselves from the tiring activities which they usually do every day. However; there are many people who have hobby listening and they always have to update towards their development. Beside that, many people need music to kill the time, to have activity companion, and to get the media for learning.

We need to understand that, music can be put in line with everything that influences the world. In music, it can take us to its world and we can get along with the rhythm and the lyrics. In our daily activities, music can influence the human cognitive ability. It can be proved that after the listeners listen to their favorite music; indirectly music will be accepted by the brain waves that can make the nerves of the brain thought become relaxed. If the brain is relaxed it will influence the human physical work performance. The mind becomes relaxed. The heart becomes peaceful; therefore, human can control himself so that he can increase his (someone's) intelligence and it is the result of listening to the music every day. Music does not only do such kinds of effect above, in the health world, music also plays important roles in a therapy practice. Therapist usually use music for health therapy to lower anxiety, help someone reduce the blood pressure, lower the stress and depression; therefore, music can influence the baby's health in the womb. All effects can be one by listening to a kind of music to the patients. Therefore, we can say that music is not only as an entertainment medium but it is also a medium to increase the human physical performance. We should keep the music existence. We need its role in the daily activities. No matter a change will change the music, the most important thing, music will always be able to stick on its fans' hearts. Besides the meaning carried in the music that has values, music also can influence the body's performance that causes the improvement of the body's performance in doing someone's activities.

\section{References}

Aguiar L (2017) Let The Music Play? Free Streaming And Its Effects On Digital Music Consumption. Information Economics and Policy 41: 1-14.

Ardivitiyanto Y (2015) Perkembangan Musik Rock Di Kota Malang Tahun 1970-2000-an: Kajian Globalisasi Dan Eksistensi Budaya. Jurnal Kajian Wilayah 6 (1): 53-69.

Campbell D (2001) Efek Mozart Bagi Anak-Anak, penerjemah Alex Tri Kantjono Widodo. Jakarta: Gramedia Pustaka Utama.

Djamal R, Rompas S, \& Bawotong J (2015) Pengaruh Terapi Musik Terhadap Skala Nyeri Pada Pasien Fraktur Di Irina A RSUP Prof. DR. R.D. Kandou Manado. E-Journal Keperawatan 3 (2): $1-6$.

Ellfira S (2015) Hubungan Karakter Musik Klasik Dan Pop-Jazz Dengan Kecerdasan Emosi (EQ). Tugas Akhir, Institut Seni Indonesia, Yogyakarta.

Faradisi F (2012) Efektivitas Terapi Murotal Dan Terapi Musik Klasik Terhadap Penurunan Tingkat Kecemasan Pasien Pra Operasi Di Pekalongan. Jurnal Ilmiah Kesehatan 5 (2).

Halim S (2002) Music as a Complementary Therapy in Medical Treatment. Medical Journal of Indonesia 11 (4): 250-257.

Hardjana S (2004) Musik Antara Kritik Dan Apresiasi. Jakarta: Penerbit Buku Kompas.

Hirzi AT (2007) Mengomunikasikan Musik Kepada Anak. MediaTor 8 (2): 201-210.

Juslin PN \& Vastfjall D (2008) Emotional Responses To Music: The Need To Consider Underlying Mechanisms. Behavioral and Brain Sciences 31 (5): 559-621.

Komariyah L (2016) Pengaruh Musik Angklung Terhadap Kualitas Hidup Wanita Lanjut Usia. Jurnal Pendidikan Keperawatan Indonesia 2 (1): 10-15.

Kurniawan NG (2016) Efektivitas Musik Klasik (Mozart) Untuk Menurunkan Kejenuhan Belajar Siswa Kelas XI SMAN 4 Yogyakarta. Jurnal Riset Mahasiswa Bimbingan Dan Konseling 5 (7): 1-10. 
Lerik MDC \& Prawitasari JE (2005) Pengaruh Terapi Musik Terhadap Depresi Diantara Mahasiswa. Sosiosains 18 (2): 209-219.

Maes PJ, Leman M, Palmer C, \& Wanderley MM (2014) Action-based Effects On Music Perception. Frontiers in Psychology 4 (1008): 1-14. https://doi.org/10.3389/fpsyg.2013.01008.

Martopo H (ed) (2008) Seni Musik Klasik Jilid 1. Jakarta: Direktorat Pembinaan Sekolah Menengah Kejuruan, Direktorat Jenderal Manajemen Pendidikan Dasar dan Menengah, Departemen Pendidikan Nasional.

McNeill RJ (2002) Sejarah Musik 1. Jakarta: Gunung Mulia.

Poutiainen A \& Lilja E (2012) Heavy Metal and Music Education. Social and Behavioral Sciences 45: 517-526. https://doi.org/10.1016/j.sbspro.2012.06.589.

Santoso DS (2002) Pengaruh Musik Terhadap Performance Fisik. Jurnal Teknik Industri 4 (1): 1-7.

Wulandari T (2009) Perbedaan Kemampuan Mengingat Ditinjau dari Gaya Belajar. Skripsi, Universitas Muhammadiyah Surakarta, Surakarta. 